\title{
Genocide Determination and the Question of Responsibility for the Darfur Victims of International Crimes
}

\author{
Tambe Endoh Fabrice
}

Faculty of Law, University of Fort Hare, PB X1314, Alice 5700, South Africa

Doi:10.5901/mjss.2014.v5n9p51

Email: fablosa88@yahoo.com

\begin{abstract}
After the cold war era the United Nations organization was formed for the purposes of maintaining international peace and security. Closely after the formation of the organization the convention for the prevention and punishment of the crime of genocide came into force as the first legal document to articulate the definition of the term 'genocide'. Viewed as a serious crime under international law, the contracting parties unanimously agree to suppress acts of genocide not only within their national jurisdiction but also within the international community as a whole. As a party to both the United Nations and the genocide convention, Sudan bears the primary responsibility to fulfill her obligation by protecting its citizens including the Darfur indigenes from acts of human rights violation that could possibly amount to genocide. This paper debates on the contemplation as to whether or not genocide actually materialized in the Darfur conflict. In conclusion, the paper decent that genocide occurred in Darfur and the perpetrators in the name of the Sudanese government and its allies the janjaweed militias should be held accountable for such acts.
\end{abstract}

Keywords: Genocide, Darfur, Customary International Law, War Crimes, Crimes against Humanity

\section{Introduction}

\subsection{Darfur and the crime of Genocide}

Diverse opinions exist as to whether the crimes committed in Darfur amount to genocide. The report of the International Commission of Inquiry in Darfur (ICID Report) states they are crimes against humanity and war crimes, while former US Secretary of State, Collin Powel, and the US State Department state that the crimes amount to genocide (Hassan, 2010. p.20). In the opinion of the ICID a number of offences could be identified to justify the perpetration of war crimes and crimes against humanity by the perpetrators. One among others include indiscriminate attacks on civilian populations by the Sudanese government and its janjaweed militias amounting to serious violations of international humanitarian law and human rights law as crimes under international law. Although war crimes and crimes against humanity are said to have occurred in Darfur, the ICID maintained that the Sudanese government did not pursue a policy to commit genocide. The report raised a number of issues to assert that the Sudanese government had no specific intention as prescribed by Art.2 of the genocide convention to commit genocide in Darfur.

\subsection{Meaning of the Term 'Genocide'}

Although there are examples of mass violence directed against identifiable groups dating back to antiquity, "genocide" as a term and a concept is of a recent origin. Lemkin, a Jewish lawyer coined the word and introduced it in 1944 (Kegley, 2007). He derived it from the Greek word "geno" for tribe or nation and the Latin word "cide" which means killing. By genocide Lemkin meant "a coordinated plan of different actions aiming at the destruction of essential foundations of the life of national groups, with the aim of annihilating the groups themselves" (Fowler, 2006. p.128).

Genocide was mentioned in paragraph 8 of the 1945 Nuremberg indictment as a description of war crimes committed by the defendants being tried before the International Military Tribunal. In 1946, the General Assembly of the UN adopted resolution 96 that described genocide as "a denial of the right of existence of entire human groups" and affirmed that genocide is a crime under international law (Fowler, 2006). Resolution 96 further set in motion the process that resulted in the adoption of the Genocide Convention on December 9, 1984. Article 1 of the latter Convention makes it clear that genocide is punishable under international law.

The heart of the substantive portion of the Genocide Convention is Article 2. Here genocide is defined as a matter of international law and the two essential components of the definition are the "actus reus" (the physical act) and the 
"mens rea" (the intention) (Fowler, 2006). It follows that an offense will amount to genocide only where there is a physical act and also a requisite 'state of mind' to commit such an act. The acts that constitute genocide are clearly stated under Article 2 of the Genocide Convention.

Genocide has previously been committed in places like Rwanda and Bosnia (Judgment of the International Court of Justice case 91, 2007. para.53). Genocide, according to Article 6 of the International Criminal Court (ICC) Statute, means any of the following acts committed with intent to destroy, in whole or in part, a national, ethnical, racial or religious group, such as: Killing members of the group; Causing serious bodily or mental harm to members of the group; Deliberately inflicting on the group condition of life calculated to bring about its physical destruction in whole or in part; Imposing measures intended to prevent births within the group and Forcibly transferring children of the group to another group.

This provision is in pari materia with Article 2 of the Genocide Convention. Both provisions make it clear that "intention" is the principal element for the crime of genocide to materialise. The Genocide Convention further provides that genocide, whether committed in time of peace or in time of war, is a crime under international law which states undertake to prevent and to punish. In the case of Prosecutor v. Kayishema and Ruzindana, the International Criminal Tribunal for Rwanda (ICTR) Trial Chamber held that the crime of genocide is considered as part of customary international law and is punishable whether committed in international or internal armed conflict (Case No. ICTR-96-1-A of 1 June 2001. para.88). Similarly, in the case of Prosecutor v. Rutanganda, the ICTR Trial Chamber stated that the Genocide Convention is undeniably considered part of customary international law (Case No. ICTR-96-03-T of 6 December 1999. para. 46). The ICTR Trial Chamber's decision in both cases falls within the context of Article 1 of the Genocide Convention. Sudan is a party to the Genocide Convention and if it has committed acts of genocide, it is in breach of its international legal obligations and therefore internationally responsible for its unlawful conduct.

Article 2 of the Genocide Convention lists four groups to be protected in the case of an internal or international armed conflict. They include national, racial, ethnic, and religious groups. In the context of Rwanda, the Tutsis who suffered a great deal against the Hutus fall under ethnic group, which the International Criminal Tribunal for Rwanda (ICTR) trial chamber further defined as a group of members, who speak the same ethnic language or come from the same ethnic origin (Case No. ICTR-96-4-T of 2 September 1998. para.92). In Darfur, the Fur, Masalit and the Zaghawa qualify as "ethnic groups" and fit in within the interpretation of Article 2 of the Genocide Convention. Darfur itself is made up of ethnic groups consisting of black Africans and Arabs.

After identifying black Africans as among the ethnic groups in Darfur, it is necessary to find out if they were subjected to the acts prescribed above in Article 2(a)-(e) of the Genocide Convention. There have been reports of violence and abuses of international humanitarian law that resulted in war crimes and crimes against humanity being committed in the territories of Rwanda and Bosnia (Oprah, 2006. para.2). The violence that erupted in Darfur in 2003 can be placed in the same category with the above mentioned cases (Human Rights Watch Darfur, 2011). According to the account by Ambassador Baba Gana Kingibile, Special Representative of the Africa Union (AU) mission in Darfur (Reeves, 2008):

On 28 September $2005, \ldots$ some reportedly 400 Janjaweed Arab militias on camel and horseback went on the rampage in Aru Sharo, Acho, and Gozmena villages in West Darfur. Our reports also indicate that... on the actual day of the attack, Government of Sudan helicopter gunships were observed overhead. This apparent coordinated land and air assault gives credence to the repeated claim by the rebel movements of collusion between the Government of Sudan forces and the Janjaweed/Arab militia. This incident, which was confirmed not only by our investigators but also by workers of humanitarian agencies and nongovernmental organisations in the area, took a heavy toll resulting in 32 people killed, 4 injured and 7 missing, and about 80 housed/shelters looted and set ablaze.

Besides the scene captured above, the ICID report identified a number of instances through which, the use of child soldiers, torture and unlawful confinement, rape and other sexual offences were carried out in a widespread and systematic manner (Reeves, 2005). However, the report concluded that some elements of war crimes and crimes against humanity occurred in Darfur but the essential part of genocide which is 'the intention to commit the act' was missing (Reeves, 2005. para.640). To clarify this ambivalence situation, one needs to digest the content of the crime of genocide with regards to "intension" as prescribed by the genocide convention.

\section{Intent to Commit Genocide in the Darfur Conflict}

In September 2004 the US Secretary of State, Collin Powell, testified before the US Congress on the conflict in Darfur. He confirmed that evidence obtained from investigations indicates that the Sudan troops and the affiliated Janjaweed militia had committed atrocities against non-Arab tribes in the region, including murder and robbery (Hassan, 2010. p.26). 
Powell added that the US State Department concluded that the atrocities constituted ethnic cleansing in Darfur for which the Sudan government and its allies among the Arab tribes in Darfur were responsible.

Powell's testimony reflected an inclination to criticise the Sudanese government and to hold it solely accountable for the events that unfolded in Darfur. In January 2005, the US administration came out in support of the findings of the ICID report and accused Sudan's judicial system of deficiency, non-transparency, and inability to deal with crimes committed in Darfur (Fowler, 2006. p.128). On their part, the Security Council subsequently referred the file on the Darfur crimes to the ICC for further clarifications (United Nations Security Council Resolution 1593. para.1).

\subsection{Requirement of intention to qualify the crime of 'Genocide'}

The required 'state of mind' that distinguishes genocide from any other crime is the "intention to destroy in whole or in part, a national, ethnic, racial or religious group as such". Thus, merely intending to commit the physical act is not enough. The perpetrators must also have a "specific" or "special" intent to destroy a protected group in whole or in part. In the case of Prosecutor v. Musema, the ICTR Appeal Chamber held that genocide required proof of intent to destroy in whole or in part a national, racial, ethnic or religious group (Case No. ICTR-96-13-A, 2000. para.166).

The Genocide Convention provided the framework within which the US Secretary of State, Collin Powell, and the US government, considered in mid-2004 whether genocide had occurred in Darfur. Applying the legal definition in Article 2 to the facts gathered by the Atrocities Documentation Team (ADT) and from other sources, it was concluded that genocide was committed in Darfur and that the government of Sudan and its militia allies, the so call Janjaweed, were responsible (Fowler, 2006).

In announcing his determination, Secretary Powell pointed to murder, rape and other physical violence committed against members of the non-Arab ethnic groups (Hamilton, 2011). This violence corresponded with the acts specified in Article 2 (a) and (b) of the Genocide Convention, namely, killing members of a group and causing serious bodily or mental harm to them. He also pointed out to the destruction of food and other means of survival of the targeted groups. In addition, he mentioned obstruction by the Sudanese government of the humanitarian assistance that the victims needed in order to survive. This conduct inflicted a large number of deaths on the targeted population in addition to those who perished from direct violence. It corresponded with the requirement in Article 2(c) of the Genocide Convention, namely, deliberately inflicting conditions of life calculated to bring about a group's physical destruction in whole or in part.

With respect to the "intention to destroy" required by Article 2 of the Genocide Convention, Secretary Powell concluded that 'intent' could be inferred from the Sudanese Government's deliberate conduct (Fowler, 2006). Inferring intent from conduct in the absence of direct evidence is widely accepted practice. The ICTR, for example, listed a number of circumstances that are relevant to determining "intent to destroy", many of which are present in the case of Darfur. Some of these circumstances are: "The general context of the preparation of the culpable acts systematically directed against the same group"; "the scale of atrocities committed"; "the general nature" of the atrocities; deliberately and systematically targeting members of some groups but not others; attacks on "the foundation of the group"; "the use of derogatory language towards members of the targeted group"; "the systematic manner of killing"; and "the relative proportionate scale of the actual or attempted destruction of a group" (Prosecutor v. Akayesu. Case No. ICTR-96-4-T, 1998. para.136).

In the case of Bosnia and Herzegovina v. Serbia and Montenegro, the International Court of Justice (ICJ) applied the Genocide Convention (Judgement of the International Court of Justice Case 91, 2007. para.291). The Court concluded that the acts committed at Srebrenica fall within Article 2 (a) and (b) of the Convention and were committed with the specific intent to destroy in part the group of the Muslims in Bosnia and Herzegovina and as such; they were acts of genocide committed by the Bosnian Serb forces in and around Srebrenica at the time of the conflict.

Although the finding of the Court that Serbia was neither directly responsible for Srebrenica genocide nor complicit in it was not unanimous, it went on to rule that Serbia had committed a breach of the Genocide Convention by failing to prevent the atrocities at Srebrenica. For not cooperating with the International Criminal Tribunal for the Former Yugoslavia (ICTY) in punishing the perpetrators of the genocide in particular, and for violating its obligation to comply with the provisional measures ordered by the Court. However, the Vice-President of Court dissented on the grounds that "Serbia's involvement as a principal actor or accomplice in the genocide that took place in Srebrenica is supported by massive and compelling evidence" (Judgement of the International Court of Justice Case 91, 2007).

In this regard, Secretary Powell's testimony to the Senate Foreign Relations Committee emphasized that the scale and scope of the murder and rape of the civilians as well as the actions of the Sudanese military and its militia allies were "a coordinated effort, not just random violence". Powell noted Khartoum's failure to cease and desist from the attacks on the non-Arab groups and its continued obstruction of humanitarian aid even after having been repeatedly put on notice by 
other governments and the UN (Hamilton, 2011).

Invoking Article 8 of the Genocide Convention, Secretary Powell called upon the UN to undertake its own investigation. Thus, the only specific outcome of the genocide determination is the UN Security Council resolution 1564, which requested that the Secretary-General appoint an International Commission of Inquiry to look into whether acts of genocide had in fact occurred and to identify perpetrators of violations of international humanitarian and human rights law. While awaiting the Commission's report, the Council decided "to remain seized with the matter" (United Nation Security Council Resolution 1564, 2004).

At the end of January 2005, the Commission issued its report, which documented the Sudanese Government's role in organizing, arming and training the Janjaweed militia (Reeves, 2005. para.507). The report laid down the responsibility for serious violations of international humanitarian and human rights law at the hands of the government and its allies, which had a pronounced ethnic dimension. Addressing the particular terms of the Genocide Convention, the Commission noted that its investigation collected substantial and reliable materials, which tend to show the occurrence of systematic killing of civilians belonging to particular tribes. There was also evidence of large-scale actions that caused serious bodily or mental harm to members of the population belonging to certain tribes, and of massive and deliberate infliction on those tribes of conditions of life bringing about their physical destruction in whole or in part. These actions, for example, include the systematic destruction of villages and crops, expelling villagers from their homes and looting their cattle (Reeves, 2005).

Although the Commission believed that this evidence could establish the physical act enumerated in Article 2(a) to (c) of the Genocide Convention, it explicitly "concluded that the Government of Sudan had not pursued a policy of genocide" based on the absence of the required "intent to destroy". The Commission acknowledged that the scale of the atrocities and racially motivated statements by the perpetrators indicated genocide intent, but asserted that "other more indicative elements" pointed out to a lack of such intent. The Commission identified three elements that are "more indicative" which are elaborated below (Reeves, 2005. para.513).

First, in some unspecified number of villages, the attackers "refrained from exterminating the whole population". As proof, the Commission referred to one village in which the government commissioner and the leader of the Arab militias executed about 227 people out of 1200 who were captured after the attack. Apparently, fifteen of the executed were on a written list brought by the perpetrators. Seven were village leaders and two hundred and five were accused of being rebels. The Commission's reference to the fact that the perpetrators did not exterminate the whole population is puzzling (Fowler, 2006. p.132). The plain language of the Convention includes an intention to destroy a group "in whole" or "in part". The Commission itself had explained that international case law establishes that the intent to destroy a group "in part" requires the intention to destroy a "considerable number of individuals" or a substantial part, but not necessarily a "very important part of the group" (Reeves, 2005. para.492).

In this particular instance, the Commission failed to offer any reason why 227 out of 1200 villages is neither a considerable number of individuals nor a substantial 'part' of the sample, especially when the community leadership was particularly targeted. At a face value the perpetrators reported assertion that the 227 murdered villagers were rebels, led the Commission to distinguish between "the intent to destroy an ethnic group as such" and "the intent to murder all those men they considered to be rebels". Yet, the Commission had previously included a number of quotes in which the perpetrators used ethnic identity, racial epithets and terms like 'Tora Bora' interchangeably (Fowler, 2006. p.132). The Commission based its decision on lack of intention. Their findings led them to conclude that the intent was not to wipe out the population but to punish, to remove support for the rebels, and to instill fear in anyone who might want to support the rebels. It happened that much of the rebels' support base was the black African population.

The whole point of the government's campaign against the civilian population of the non-Arab ethnic groups relied on equating ethnicity with rebellion, rendering it nonsensical to distinguish 'intent to destroy' those ethnic groups from 'intent to murder' rebels. The targets were by the Sudanese Government's apparent definition, one and the same.

The second element cited by the Commission as indicating a lack of genocidal intent is that the Sudanese Government collected survivors of destroyed villages in camps for internally displaced persons (IDPs) (Reeves, 2005. para.515). Here, it generally allows humanitarian organizations to help the population by providing food, clean water, medicine and logistical assistance. This begs the question of whether the direct violence (i.e. murdering and raping) was of sufficient scale to evince the intent to destroy the targeted groups "in part", even though there are survivors who are not murdered out-rightly. The Commission offered no rationale why these elements will be more indicative of intent than the scale and systematic nature of direct violence. It also skirts the issue of government obstacles to humanitarian aid, which were reduced but not eliminated only as a result of concerted international pressure in mid-2004. It also did not pay attention to the continuous attacks against those who venture out of the camps in search of essentials of life such as firewood, water and food (Fowler, 2006. p.132). 
The third element identified by the Commission is that an unspecified number of villages with a mixed ethnic composition had not been attacked at the time the Commission was undertaking its investigation. It is difficult to know what to make of this assertion as the Commission makes no effort to contextualize it (Fowler, 2006). For example, it does not quantify the number of untouched villages in relation to the number of villages destroyed, or the relationship between the number of inhabitants of such villages to the number of civilians who were subject to murder, rape or displacement. More importantly, previously unharmed villages were attacked and destroyed at the time that the Commission was researching and writing its report and such attacks are still ongoing in the Darfur (Reeves, 2008).

The Commission's final paragraph regarding intent is perhaps the most difficult to define (Reeves, 2005. para.517). It recounts a single anecdote from "a reliable source" in which one man was not killed when attackers took two hundred camels from him. The ICID report explains that the man's younger brother resisted the theft of his own camel and was shot dead. The Commission concluded that "in this instance the special intent to kill a member of a group to destroy the group as such was lacking, the murder being only motivated by the desire to appropriate cattle belonging to the inhabitants of the village".

Perhaps, the requisite intent may indeed have been missing in one instance, but the relationship of that one instance to the overall situation in which pillaging and destruction appears to have been directed to bring about the destruction of the livelihoods and means of survival of the targeted population remains unclear.

\subsection{Comparing the Evidence}

Although Secretary Powell and the Commission operated from a largely similar factual base, they reached diametrically opposite conclusions on the question of genocide. One explanation for this may be an issue that neither addressed explicitly the weight of evidence necessary to reach a conclusion. In these circumstances, how much evidence of genocidal intent, in terms of quantity and credibility, is necessary relative to evidence of lack of intent?

The Commission hinted that it was applying an extremely high standard in assessing the evidence (Reeves, 2005. para.503). Courts and other bodies charged with establishing whether genocide has occurred must, however, be very careful in the determination of subjective intent. It then quoted with approval the ICTY for the proposition that "convictions for genocide can be entered only where intent has been unequivocally established" (Reeves, 2005). In essence, the Commission adopted for itself the standard that intent must be shown "beyond reasonable doubt" the weight of evidence necessary to convict an individual in a criminal trial as stated in Article 66(3) of the Statute of the ICC. This is the most exacting burden imaginable, an understandable burden for a prosecutor to bear when a court is deciding the life or liberty of an individual.

Viewed in the context of this burden of proof, the Commission's analysis of the issue of intent to commit genocide is less mysterious. The three elements it cited, though not particularly compelling, do cast some doubts as to the existence of a genocidal intent on the part of the Sudanese Government. One might well conclude that the evidence of genocidal intent that is adduced in the Commission's report, though quite strong, does not establish such intent "beyond reasonable doubt".

However, the Commission was not acting in accordance with its duty. The Commission was not a court of law, nor was it adjudicating the fate of individual defendants. The liberty of an accused defendant did not turn on its decision. To the contrary, the Commission was only called upon to make a threshold finding on the basis of which the UN Security Council would decide to take additional action, including referring the situation to the ICC for a full-fledged criminal investigation.

A careful examination of the Statute of the ICC reveals the Commission's erred in applying "beyond reasonable doubt" standards. The Statute contemplates several stages through which a case precedes, each stage requiring that a separate weight of evidence be met. When a situation is referred to the ICC, the prosecutor is required to initiate an investigation unless "there is no reasonable base to proceed" as stated in Article 36 of the Statute. Having conducted an investigation, the prosecutor may seek an arrest warrant if he/she can establish "reasonable grounds to believe that the person committed a crime within the jurisdiction of the court" (Rome statute of the ICC, Art. 59). The court is next called up to confirm the charges, which it will do if the prosecutor offers "sufficient evidence to establish substantial grounds to believe that the person committed the crime charged" (Rome Statute of the ICC, Art. 61). Finally, an individual can only be convicted if the court is "convinced of the guilt of the accused beyond reasonable doubt" (Rome Statute of the ICC, Art. 66(3)).

In this regard, between "no reasonable bases to proceed" and "beyond reasonable doubt" lies a continuum in which the required weight of evidence steadily and appropriately mounts as the process moves forward. To eliminate this continuum requires a prosecutor to establish guilt beyond reasonable doubt otherwise a condition of launching an 
investigation would be inappropriate (Fowler, 2006. p.135). Yet, that is the standard of proof apparently applied by the Commission, in spite of the fact that its investigation was prefatory to any judicial action. The Commission's application of this standard is all the more erroneous in the light of the constraints placed upon it by the amount of time available as well as the continued commission of the very crime it was supposed to investigate. It was not conceivable to reach a conclusion "beyond reasonable doubt" on an issue as complex and problematic as genocidal intent.

Secretary Powell did not articulate what weight of evidence he looked for in making his determination. However, the tenor of his analysis, which emphasizes the necessarily limited nature of the Atrocities Documentation Team (ADT) investigations and other available information, suggests that he was in essence asserting a reasonable basis for concluding that the Sudanese Government and its Janjaweed allies had committed genocide.

\section{The Role of Customary International Law}

In the Barcelona Traction case (Case concerning the Barcelona Traction, Light and Power Company Limited, 1970), the ICJ stated:

... In particular, an essential distinction should be drawn between the obligations of a state towards the international community as a whole, and those arising vis-à-vis another state in the field of diplomatic protection. By their very nature the former are the concerns of all states. In view of the importance of the rights involved, all states can be held to have a legal interest in their protection; they are obligations erga omnes.

Both conventional and customary international law contains a category of higher norms, also known as peremptory norms or norms of jus cogens which are essential for the functioning of the international community, and therefore their breach entails serious consequences. These for example, include rules prohibiting slavery, genocide, colonialism, torture, apartheid, international wars of aggression, and the body of laws codified under international humanitarian law. With respect to the latter, a number of states refer in their military manuals international humanitarian law as relevant to internal armed conflict. The German Manual for example states that (The German Manual of Humanitarian Law in Armed Conflict, 1992. p.24):

In a non-international armed conflict each party shall be bound to apply as a minimum, the fundamental humanitarian provisions of international law embodied in the four 1949 Geneva Conventions (common Article 3), the 1954 Cultural Property Convention (Article 19 and the 1977 Additional Protocol II. German Soldiers, like their Allied are required to comply with rules of international humanitarian law in the conduct of military operations in all armed conflicts, however such conflicts are characterised.

The UK Manual also set out what the British Government considers to be "Certain principles of customary international law which are applicable to internal conflicts" (The British Manual on the Law of Armed Conflict, 2004. p.384398). Other states have adopted the same approach in respect of rules of international humanitarian law. Before the adoption in 1968 of the General Assembly resolution 2444 affirming a set of principles to be complied with in any armed conflict (UN General Assembly Resolution 2444, 1968), the US representative stated in the Third Committee that the principles proclaimed "constituted a reaffirmation of existing laws" (UN Doc. A/C3/Sr.1634, 1968. p.2). In the same vein in 1987, the US Deputy Legal Advisor to the State Department stated that "the basic core of Protocol II is, of course, reflected in common Article 3 of the 1949 Geneva Conventions and therefore is, and should be, part of general accepted customary law (Martin et al, 1987. p.430). This precisely includes prohibitions on violations towards persons taking no active part in hostilities, hostage-taking, degrading treatment and punishment without due process.

A fundamental rule on the distinction between combatants and civilians and the protection of civilians, especially against violence to life and person, in particular murder, is laid down in common Article 3 of the 1949 Geneva Conventions. Also, a similar provision has been set out in paragraph 15 of the 2004 British Manual on the Law of Armed Conflict.

In a report made pursuant to paragraph 5 of the UN Security Council resolution 837 of 1993 on the investigation into the 5 June 1993 attack on UN Forces in Somalia, the UN Secretary-General noted that (UN Doc. S/26351, 1993):

The [Geneva] Conventions were designated to cover inter-state wars and large-scale civil wars. But the principles they embody have a wider scope. Plainly, as part of contemporary international customary law, they are applicable wherever political ends are sought through military means. No principle is more central to humanitarian law of armed conflict than the obligation to respect the distinction between combatants and non-combatants. That principle is violated and criminal responsibility thereby incurred when organisations deliberately target civilians or otherwise demonstrate a wanton indifference to the protection of non-combatants.

The report of the Inter-American Commission on the human rights situation in Colombia issued in 1999 also states that international humanitarian law prohibits (Report on the Human Right Situation in Colombia, 1999. para.40):

The launching of attacks against the civilian population and requires the parties taking part in an armed conflict, at all times, to make a distinction between members of the civilian population and parties actively taking part in hostilities and 
direct attacks only against the latter and, inferentially, other legitimate military objectives.

This rule was reaffirmed by the Government of Sudan and the rebel movements. The Humanitarian Cease Fire Agreement on the conflict in Darfur states that, each party undertakes to "refrain from any violence or any other abuse on civilian population" (Humanitarian Cease Fire Agreement in Darfur, 2004. Art. 2). The Protocol on the Improvement of the Humanitarian Situation in Darfur also provides that, the parties undertake "to take all steps required to prevent all attacks, threats, intimidation and any other form of violence against civilians by any party or group, including the Janjaweed and other militias" (Protocol on the Involvement of the Humanitarian Situation in Darfur, 2004. Art.2(1)).

The two agreements above suggest that the parties involved in the Darfur conflict considered common Article 3 of the Geneva Conventions as binding upon them and by the implication of customary international law they ought to face legal sanctions. The statute of the ICJ provides that the Court whose function is to decide in accordance with international law such disputes as is submitted to it, shall apply: International custom, as evidence of a general practice accepted as law and, the general principles of law recognized by civilized nations (Statute of the International Court of Justice, 1945. Art. 38(1)(b)(c)):

Sudan is therefore bound to respect the rules that prohibit the violation of customary international law including the international bombing of civilians, the rule prohibiting attacks on non-military objects and the rule regarding precautions required when attacking military objects.

The above justification has also been affirmed under case law. In the Tadic Case, the ICTY stated that deliberate attacks on civilians are prohibited by customary international law (Omer, 2008. p.1). In its Advisory Opinion on Legality of the Threat of Use of Nuclear Weapons, the ICJ also held that "States must never make civilians the object of attack" (The International Court of Justice in Legal Consequences of the Construction of a Wall in the Occupied Palestinian Territory, 2004. para.78). The general rule was restated and specified in Article 51(2) of Additional Protocol I of 1977 where it was provided "The civilian as such, as well as individual civilians, shall not be the object of attack. Acts or a threat of violence, the primary purpose of which is to spread terror among the civilian population is prohibited". This is pari materiae to Article 13(2) of Additional Protocol II of 1977 and Article 8(2)(e)(i) of the Rome Statute of the ICC.

Indiscriminate attacks on civilians, even if there are few armed elements among the latter, are therefore prohibited, and this rule is deemed to be part of customary law. It has also been codified as restated in Article 13 of Additional Protocol II which is regarded as a provision codifying Customary International law.

In the Prosecutor v. Tadic case, the ICTY Trial Chamber held that "It is clear that the targeted population [of a crime against humanity] must be predominantly civilian in nature. The presence of some non-civilian elements in the midst does not change the character of the population (Prosecutor v. Tadic, Case No. IT-94-1, 1996. para.638). In a press release pertaining to the conflict in Lebanon in 1983, the International Committee of the Red Cross (ICRC) also emphasised that "the presence of armed elements among the civilian population does not justify the indiscriminate shelling of women, children and old people (International Committee of the Red Cross, Press release No. 1474, 1983).

Attacks directed to unarmed civilians and/or the obstruction of units or vehicles involved in humanitarian assistance undertaken by the UN is prohibited; it falls under the protection given to civilian objects under the international law of armed conflict. The UN Security Council resolution 1502 is instructive in this regard (United Nations Security Council Resolution 1502, 2003. para.3). This provision is pari materiae with Article 8(2)(e)(iii) of the ICC Statute and Article 4(b) of the Statute of the Special Court for Sierra Leone. The British Manual of the Law of Armed Conflict concludes that, dwellings and other installations that are used only by civilian population should not be the object of military operations (United Nations General Assembly Resolution 2444, 1968).

Sudan should bear responsibility and take precautions in order to minimise incidental loss and damage that may result from attacks. Each party to a conflict must do everything feasible to ensure that targets are military objects and the means or methods of combat would minimise loss of civilians. The military Manual of Benin provides that (The Benin Military Manual, 1995):

Precautions must be taken in choice of weapons and methods of combat in order to avoid civilian losses and damages to civilian objects. The direction and the moment of an attack must be chosen so as to reduce civilian losses and damages to civilian objects as much as possible.

Sudan also has an obligation to ensure that attacking military objectives and the resultant incidental loss to civilians is disproportionate to the military gain anticipated. In Prosecutor v. Zoran Kupreskic et al, the ICTY Trial chamber held that (Prosecutor v. Kupreskic et al. 2000. para.859):

Even if it can be proved that the Muslim population of Amici [a village in Bosnia and Herzegovina] was not entirely civilian but comprise some armed elements, still no justification would exist for widespread and indiscriminate attacks against civilians. Indeed, even in a situation of full-scale armed conflict, certain norms still serve to unambiguously outlaw such conduct, such as rules pertaining to proportionality. 
The Rome Statute prohibits destruction and devastation not justified by military necessity (Rome Statute of the ICC. Art. 8(2)(e)(xii)). This is also contained in Article 23(g) of the Hague Regulations of 1907 which states that "to destroy or seize the enemy's property is prohibited, unless such destruction or seizure is imperatively demanded by the necessities of wars". Article 50 of Geneva Convention I; Article 51 of Geneva Convention II; Article 147 of Geneva Convention IV; and Article 51(1) of Additional Protocol I also provide for the prohibition of extensive destruction and appropriation of property not justified by military necessity and carried out unlawfully and wantonly.

Article 14 of Additional Protocol II, which is also stated in paragraph 15 of the 2004 British Manual on the Law of Armed Conflict, provides that the right to life is a non-derogable human right. Violence to the life and person of civilians is prohibited, whatever method is adopted to achieve it. It follows that the destruction of crops, foodstuffs, and water sources, to such an extent that starvation is likely to follow is prohibited.

Attacks on works and installations containing dangerous forces are prohibited by Article 15 of Additional Protocol II to the Geneva Convention of 1949 while Article 16 of the same Protocol protects cultural objects and places of worship. Article 8(2)(e)(viii) of the ICC Statute and Article 17 of Additional Protocol II prohibits forcible transfer of civilians. The customary international humanitarian law regime governing conflicts not of an international character extends protection from acts of murder, torture and other acts prohibited by common Article 3 and these cover:

Persons taking no active part in the hostilities, including members of armed forces who have laid down their arms and those placed hors de combat by sickness, wounds, detention, or any other cause without any adverse distinction, or any other cause without any adverse distinction founded on race, colour, religion or faith, sex, birth or wealth, or any other similar criteria.

Sudan has an obligation under common Article 3(2) of the 1949 Geneva Conventions to protect the wounded and the sick. The enlistment of children under the age of 15 years into armed forces or groups has been prohibited by two treaty rules. These are Article 8(2)(e)(vii) of the ICC Statute and Article 4(c) of the Statute of the Special Court for Sierra Leone. Article 38 of the CRC and the Protocol to the Convention on the Right of a Child on the Involvement of Children in Armed Conflict considers the minimum age of persons directly taking part in an armed conflict to be 18 years.

After looking at the relevant rules applicable to the Darfur conflict, it is worth noting that to a larger extent the Sudanese Government was prepared to regard some general principles as binding. These are rules contained in the two Additional Protocols of 1977 although formally Sudan is not a state party to these Protocols. The principles contained in the Protocols on the Establishment of Humanitarian Assistance in Darfur, signed on $8^{\text {th }}$ April 2004 by the Government of Sudan with the Sudan Liberation Army and the JEM provides that (Sudan: Protocol on the Establishment of Humanitarian Assistance in Darfur, 2004):

The concept and execution of the humanitarian assistance in Darfur will conform to the international principles with a view to guarantee that it will be credible, transparent, inclusive and notably: the 1949 Geneva Convention and its two 1977 Additional Protocols, the 1948 Universal Declaration on Human Rights, the 1966 International Convention on Civil and Public Rights, the 1951 Geneva Convention on Refugees, the Guiding Principles on Internal Displacement (Deng Principles) and the provisions of General Assembly Resolution 46/182.

Article 8(a) of the Statute of Mission Agreement (SOMA) on the Establishment and Management of the Cease Fire Commission (CFC) in the Darfur region entered between the Government of Sudan and the AU of $4^{\text {th }}$ June 2004 is also important. It provides that:

The African Union shall ensure that the CFC conducts its operation in the Sudan with full respect for principles and rules of international conventions applicable to the conduct of military and diplomatic personnel. These international conventions include the four Geneva Conventions of 12 August 1949 and their Additional Protocols of 8 June 1977 and the UNESCO Convention of 14 May 1954 on the Protection of Cultural Property in the event of armed Conflict and the Vienna Convention on Diplomatic Relations of 18 April 1961.

Article 9 of SOMA concludes that:

The CFC and the Sudan shall therefore ensure that members of the respective military and civilian personnel are fully acquainted with the principles and rules of the above mentioned international instruments.

Considering the points raised above, one can assume that entry into the above agreements by parties to a conflict indicates acceptance of rules applicable to the conduct of internal hostilities, and, in particular, the principle that civilians must not be targets of attacks. Viewed in the context above, the contracting parties intended to comply with various international humanitarian treaties, including the two Protocols additional to the Geneva Convention, even though the Protocols per se are not binding qua treaties on the Government of Sudan. Sudan should respect the rules which prohibit bombing of civilians, those prohibiting attacks on non-military object and the rule regarding precautions required when attacking military object. 


\section{Conclusion}

In the final analysis, Secretary Powell did not articulate what weight of evidence he looked for in making his determination. However, the tenor of his analysis, which emphasizes the necessarily limited nature of the Atrocities Documentation Team (ADT) investigations and other available information, suggests that he was in essence asserting a reasonable basis for concluding that the Sudanese Government and its Janjaweed allies had committed genocide. His determination was never left in isolation though; it was strongly supported by the ICC pre-trial chamber in 2009. The latter held strong allegations of genocide intent against President Omar Al Bashir and maintained that the appeal chamber should confirm such charges. Judging from the forgoing, the Sudanese government has shown reluctance in putting a stop to human right violations in the Darfur region of The Sudan. The government should be held accountable for atrocities committed in Darfur as they bear the primary responsibility to protect all Sudanese citizens including those from the Darfur region.

\section{Reference}

Case concerning the Barcelona Traction, Light and Power Company Limited (Belgium v Spain) Second Phase. 1970 ICJ3, at 33. See also the Vienna Convention on the Law of Treaties Art 53 and 64.

Case No. ICTR-96-03-T of 6 December 1999.

Case No. ICTR-96-13-A of 27th January 2000.

Case No. ICTR-96-1-A of 1 June 2001.

Case No. ICTR-96-4-T of 2 September 1998.

Fowler J. (2006). Genocide in Darfur: Investigating the Atrocities in the Sudan. Routledge Taylor and Francis Group New York.

Hamilton R. (2011). Fighting for Darfur: Public Action and the Struggle to stop Genocide. Macmillan Publishers, New York.

Hassan A. (2010). Dimensions of the Darfur crisis and its consequences: An Arab perspective. African Security Review Journal. Volume 19 , No.1. Routledge Taylor and Francis Group South Africa.

Human Rights Watch Darfur, 2011. Sudan: New attacks on Civilians in Darfur. Available at http://www.hrw.org/news/2011/01/08/sudan-newattack-civilians-darfur

Humanitarian Cease Fire Agreement in Darfur, entered into force on 8 April 2004. Art. 2.

International Committee of the Red Cross, Press release No. 1474, Geneva, 4 November 1983.

International Humanitarian Law: A Workshop on Customary International Law and the 1977 Protocols Additional to the 1949 Geneva Conventions. American International Law Review. Volume 2, Issue 2.

Judgement of the International Court of Justice. Case 91 of 26 February 2007.

Kegley C. (2007). World Politics: Trends and Transformation. Wadsworth, USA.

Martin P. et al. (1987). The Sixth Annual American Red Cross-Washington College of Law Conference on

Omer Y. 2008. The Darfur situation and the ICC: An appraisal. Journal of Politics and Law, vol.1, No.3.

Oprah W. (2006). Survivors' stories from genocide in Bosnia, Rwanda and Darfur. Available at http://www.oprah.com/oprahsbookclub /modernDay-Genocide-Survivors-Stories-from-Bosnia-Rwanda-Darfur.

Prosecutor v, Tadic, Case No. IT-94-1, Trial Chamber 7 May 1996.

Prosecutor v. Akayesu. Case No. ICTR-96-4-T of 2 September 1998.

Prosecutor v. Kupreskic et al. ICTY Trial Chamber Judgement of 14 January 2000. Case No. IT-95-16-T.

Protocol on the Involvement of the Humanitarian Situation in Darfur, entered into force on 9 November 2004. Art.2(1).

Reeves E. (2005). Report of the International Commission of Inquiry on Darfur to the UN Secretary General. IDEAS Publishers, New York.

Reeves E. (2008). Sudan resumes Civilians destruction in West Darfur-Sudan Tribune. Available at http://www.Sudantribune.com /Sudanresume-civilian-destruction, 26048

Report on the Human Rights Situation in Colombia, Doc. OAS/Ser. L/V/II. 102. Doc. 9 rev. 1, 26 February 1999.

Rome Statute of the International Criminal Court. A/CONF.183/9 of 17 July 1998.

Sudan: Protocol on the Establishment of Humanitarian Assistance in Darfur of $8^{\text {th }}$ April 2004. Available at http://reliefweb.int/report /Sudanprotocol-establishment-humanitarian-assistance-darfur.

The Benin Military Manual of 1995, Practice relating to Rule 17. Choice of means and Method of Warfare. Available at http://www.icrc.org/customary-ihl/eng/docs/v2_cou_bj_rule17

The British Manual of the Law of the Armed Conflict, UK Military of Defence, Oxford, Oxford University Press, 2004.

The German Manual of Humanitarian Law in Armed Conflict, Federal Ministry of Defence of the Federal Republic of Germany, VRII 3 August 1992.

The International Court of Justice in Legal Consequences of the Construction of a Wall in the Occupied Palestinian Territory (Advisory Opinion of 9 July 2004) 43 ILM 1009.

UN Doc. A/C.3/Sr. 1634 (1968).

UN Doc. S/26351, 24 August 1993.

United Nation Security Council Resolution 1593 of 31/03/2005, Press Release: SC/8351. United Nations, New York.

United Nations General Assembly Resolution 2444 of 19/12/1968. Doc A/72/18 (1968).

United Nations Security Council Resolution 1502 of 26/8/2003. Press Release SC/7856. United Nations, New York.

United Nations Security Council Resolution 1564 of 18/09/2004, Press Release: SC/8191. United Nations, New York. 